\title{
Rate Constants of Hydroperoxyl Radical Addition to Cyclic Nitrones: A DFT Study
}

\author{
Frederick A. Villamena ${ }^{1,2,}{ }^{*}$, John K. Merle ${ }^{4}$, Christopher M. Hadad ${ }^{4,}{ }^{*}$, and Jay L. Zweier*2,3 \\ 1 Department of Pharmacology, The Ohio State University, Columbus, Ohio, USA 43210. \\ 2Center for Biomedical EPR Spectroscopy and Imaging, The Davis Heart and Lung Research Institute, The \\ Ohio State University, Columbus, Ohio, USA 43210. \\ 3Division of Cardiovascular Medicine, Department of Internal Medicine, College of Medicine, The Ohio \\ State University, Columbus, Ohio, USA 43210.
}

4Department of Chemistry, The Ohio State University, Columbus, Ohio, USA 43210.

\section{Abstract}

Nitrones are potential synthetic antioxidants against the reduction of radical-mediated oxidative damage in cells, and as analytical reagent for the identification of $\mathrm{HO}_{2}{ }^{\circ}$ and other such transient species. In this work, the PCM/B3LYP/6-31+G(d,p)//B3LYP/6-31G(d) and PCM/mPW1K/6-31 $+\mathrm{G}(\mathrm{d}, \mathrm{p})$ density functional theory (DFT) methods were employed to predict the reactivity of $\mathrm{HO}_{2}{ }^{\circ}$ with various functionalized nitrones as spin traps. The calculated second-order rate constants and free energies of reaction at both levels of theory were in the range of $10^{0}-10^{3} \mathrm{M}^{-1} \mathrm{~s}^{-1}$ and 1 to -12 $\mathrm{kcal} \mathrm{mol}^{-1}$, respectively, and the rate constants for some nitrones are on the same order of magnitude as those observed experimentally. The trend in $\mathrm{HO}_{2}{ }^{\bullet}$ reactivity to nitrones could not be explained solely on the basis of the relationship of the theoretical positive charge densities on the nitronyl-C, with their respective ionization potentials, electron affinities, rate constants, or free energies of reaction. However, various modes of intramolecular $\mathrm{H}$-bonding interaction were observed at the transition state (TS) structures of $\mathrm{HO}_{2}{ }^{\circ}$ addition to nitrones. The presence of intramolecular $\mathrm{H}$ bonding interactions in the transition states were predicted and may play a significant role towards a facile addition of $\mathrm{HO}_{2}{ }^{\bullet}$ to nitrones. In general, $\mathrm{HO}_{2}{ }^{\bullet}$ addition to ethoxycarbonyl- and spirolactamsubstituted nitrones, as well as those nitrones without electron-withdrawing substituents, such as 5,5dimethyl-pyrroline $N$-oxide (DMPO) and 5-spirocyclopentyl-pyrroline $N$-oxide (CPPO), are most preferred compared to the methylcarbamoyl-substituted nitrones. This study suggests that the use of specific spin traps for efficient trapping of $\mathrm{HO}_{2}{ }^{\circ}$ could pave the way toward improved radical detection and antioxidant protection.

\section{Introduction}

Superoxide radical anion $\left(\mathrm{O}_{2}{ }^{\bullet}\right)$ has attracted considerable attention over the last 3 decades because it has been shown that $\mathrm{O}_{2}{ }^{--}$and $\mathrm{O}_{2}{ }^{--}$-derived reactive oxygen species (ROS), such as $\mathrm{HO}^{\bullet}, \mathrm{HO}_{2}{ }^{\bullet}, \mathrm{RO}_{2}{ }^{\bullet}, \mathrm{RO}^{\bullet}, \mathrm{CO}_{3}{ }^{-}$and $\mathrm{CO}_{2}{ }^{-}$; as well as non-radicals, such as $\mathrm{H}_{2} \mathrm{O}_{2}, \mathrm{HOCl}$ and $\mathrm{ROOH}$, in unregulated concentrations are critical mediators of pathogenesis for various diseases. ${ }^{1}$ The formation of hydroperoxyl radical $\left(\mathrm{HO}_{2}{ }^{\circ}\right)$ from $\mathrm{O}_{2}{ }^{-}$is relevant in both chemical

\footnotetext{
* Correspondence to: Frederick.Villamena@osumc.edu , Fax: (614)-688-0999. hadad.1@osu.edu, Fax: (614)-292-1685; Jay.Zweier@osumc.edu, Fax: (614)-247-7799..

Supporting Information Available. Energies, enthalpies, and free energies for all spin traps and their corresponding spin adducts are available as supporting information. This information is available free of charge at http://pubs.acs.org
} 
and biological systems. For example, in simple chemical systems, $\mathrm{HO}_{2}{ }^{\bullet}$ has been shown to be produced from $\mathrm{O}_{2}{ }^{-}$by a proton-transfer reaction from phenol or one-electron reduction of $\mathrm{O}_{2}$ in the presence of $\mathrm{HClO}_{4}{ }^{2}$ Furthermore, the presence of a small equilibrium concentration of $\mathrm{HO}_{2}{ }^{\bullet}$ in neutral $\mathrm{pH}\left(\mathrm{pK}_{\mathrm{a}}\right.$ for $\mathrm{HO}_{2}{ }^{\bullet}$ is $4.8^{3}$ or $\left.4.4^{4}\right)$ can contribute to $\mathrm{O}_{2}{ }^{\bullet-}$ instability via a dismutation reaction with a reaction rate of $k=9.7 \times 10^{7} M^{-1} \mathrm{~s}^{-1} .5$

The generation of $\mathrm{HO}_{2}$ is relevant in the initiation of lipid peroxidation in cellular systems. 6 In vivo rat heart studies show that the ischemic period (a condition by which the tissues or organs are deprived of blood flow) and immediate reperfusion have enhanced oxygen radical production 7,8 and are accompanied by ischemia-induced acidosis. ${ }^{9}$ These two processes by which $\mathrm{O}_{2}{ }^{-}$can be generated under acidic conditions may have detrimental consequences, resulting in oxidative damage to cellular systems as $\mathrm{HO}_{2}{ }^{\circ}$ is a stronger oxidizer than $\mathrm{O}_{2}{ }^{\circ}$ $\left(E^{o \prime}=1.06\right.$ and $0.94 \mathrm{~V}$, respectively). ${ }^{5}$

Spin trapping 10 with cyclic nitrones in combination with electron paramagnetic resonance (EPR) spectroscopy has been the method of choice for detection of ROS, particularly for $\mathrm{O}_{2}{ }^{--}$in biological systems. However, it is not clear if the resulting nitrone- $\mathrm{O}_{2} \mathrm{H}$ adduct observed by EPR is initially formed from spin trapping of $\mathrm{O}_{2}{ }^{-}$or $\mathrm{HO}_{2} \cdot 11,12$. Therefore, a comparison of the second-order rate constants for the direct addition of $\mathrm{HO}_{2}{ }^{\bullet}$ and $\mathrm{O}_{2}{ }^{-}$to cyclic nitrones in solution can provide valuable information on to the nature of the radical species formed, and hence, be useful in elucidating mechanisms which may involve radical generation in cellular systems.

Nitrones have also been employed as intermediates in the synthesis of natural products ${ }^{13}$ and therapeutic agents. ${ }^{14-16}$ For example, the linear-nitrone, disodium-[(tert-butylimino)-methyl] benzene-1,3-disulfonate $\mathrm{N}$-oxide (NXY-059) is in clinical trials in the USA as a potential therapeutic for neurodegenerative disease. ${ }^{17}$ Moreover, the cyclic nitrones, 5,5dimethylpyrroline $\mathrm{N}$-oxide (DMPO) and 5-(diethoxyphosphoryl)-5-methyl-1-pyrroline $\mathrm{N}$ oxide (DEPMPO) (see Chart 1) has been shown to exhibit cardioprotective properties upon its perfusion in a rat's heart after ischemia. ${ }^{18}$ However, questions arise regarding the mechanism providing the antioxidant property of nitrones, ${ }^{15,19}$ since for example, DMPO reactivity with $\mathrm{O}_{2}{ }^{-2}$ at physiological $\mathrm{pH}(\sim 7)$ is slow, $k=\sim 10 \mathrm{M}^{-1} \mathrm{~s}^{-1}$ and at $\mathrm{pH}$ 5, the rate is on the order of $10^{3} M^{-1} \mathrm{~s}^{-1} .20$ Therefore, the significantly higher rate of spin trapping of $\mathrm{HO}_{2}{ }^{\circ}$, as compared to $\mathrm{O}_{2}{ }^{\circ}$, with DMPO may partly account for the antioxidant properties of nitrones. However, other mechanisms for the protective property of nitrones against oxidants have also been proposed. ${ }^{15,16}$ Boyd and Boyd ${ }^{21}$ reported the energetics of spin trapping of $\mathrm{HO}_{2}{ }^{\circ}$ by a prototype nitrone, $\mathrm{H}_{2} \mathrm{C}=\mathrm{NHO}$, with $\Delta E_{\mathrm{MP} 2}=-141 \mathrm{~kJ} / \mathrm{mol}(-33.7 \mathrm{kcal} / \mathrm{mol})$ at the MP2 $/ 6-31 \mathrm{G}$ $(\mathrm{d}, \mathrm{p}) / / \mathrm{HF} / 6-31 \mathrm{G}(\mathrm{d})$. Moreover, we previously reported theoretical free energies for $\mathrm{O}_{2}{ }^{-0}$ and $\mathrm{HO}_{2}{ }^{\circ}$ addition to nitrones that have average $\Delta G_{\mathrm{rxn}, \mathrm{aq}, 298 \mathrm{~K}}=10.0 \pm 3.0$ and $-7.0 \pm 1.6 \mathrm{kcal} / \mathrm{mol}$, respectively. 22

Correctly interpreting the nature of radical species formed in solution is important to accurately elucidate the mechanism(s) for radical production in chemical ${ }^{23}$ and biological systems. ${ }^{8,24}$ In a separate study, ${ }^{25}$ we predicted, and experimentally determined, the bimolecular rate constants for $\mathrm{O}_{2}{ }^{-}$addition to various nitrone spin traps. However, this work will focus on the prediction of second-order rate constants for $\mathrm{HO}_{2}{ }^{\circ}$ addition to various cyclic nitrones. So far, most of our theoretical work has focused on the prediction of thermodynamic parameters for the spin-trapping of $\mathrm{HO}_{2} \cdot{ }^{22}$ Although thermodynamic data provide insight into the favorability for formation of certain products, they provide no direct information in order to predict the relative rates by which spin trapping occurs. In this study, the second-order rate constants $\left(k_{2}\right)$ in solution for $\mathrm{HO}_{2}{ }^{\circ}$ addition to a variety of important nitrones were theoretically predicted and found to agree well with available experimental values. 


\section{Computational Methods}

\section{General Procedure}

Gaussian 03 (Revision B.05) was used for all calculations. ${ }^{26}$ Hybrid density functional theory 27 was employed to obtain optimized geometries and vibrational frequencies for all stationary points at the B3LYP/6-31G(d) and mPW1K/6-31+G(d,p) levels. ${ }^{28}$ The mPW1K calculations were initiated by requesting iop

$(5 / 45=10000428,5 / 46=05720572,5 / 47=10001000)$ in the route card. The mPW1K method has been shown by Truhlar and co-workers to be very effective for determining transition state (TS) structures and barrier heights for $\mathrm{H}$-atom transfer reactions. ${ }^{29}$ Single-point energies on the optimized B3LYP/6-31G(d) geometries were obtained at the B3LYP/6-31+G(d,p) level. The effect of solvation was investigated via single-point energy calculations at the B3LYP/6 $-31+G(d, p)$ level using the polarizable continuum model (PCM) to represent water. ${ }^{30}$ Stationary points, as minima for both the nitrone spin traps and their respective $\mathrm{HO}_{2}{ }^{\circ}$ adducts, were determined to have zero imaginary vibrational frequencies as derived from a harmonic vibrational frequency analysis at the level at which the stationary points were optimized. Scaling factors of $0.9806^{31}$ and $0.9515^{32}$ were used for zero-point vibrational energy (ZPE) corrections for the B3LYP and mPW1K geometries, respectively. Free energies were obtained from the calculated thermal and entropic corrections at $298 \mathrm{~K}$ using the unscaled vibrational frequencies. For the minima, spin contamination values for the radical adducts are negligible, i.e., $0.75<\left\langle S^{2}\right\rangle<0.80$ (see Tables S2-S7). Spin densities (populations) and charge densities were obtained from a natural population analysis (NPA) of the electronic wavefunctions at the PCM/B3LYP/6-31+G(d,p)//B3LYP/6-31G(d) and PCM/mPW1K/6-31+G(d,p) levels. ${ }^{33}$

Initial nitrone and spin-adduct structures for transition state (TS) searches were chosen based on the most stable conformer/configuration resulting from the PCM aqueous phase energies. Transition states (TS) were confirmed to have one imaginary vibrational frequency, and furthermore, shown to be connected to the desired reactant and product by displacement along the normal coordinate (typically 10\%) for the imaginary vibrational frequency in the positive and negative directions followed by careful minimization using opt $=$ calcfc. Hence, all $\mathrm{HO}_{2}{ }^{\circ}$ adduct structures reported here are the result of minimizing the energy of the displaced TS structures.

To predict rate constants, we examined the potential energy surfaces and located maxima, and we have been successful in locating a variety of TS's for such reactions in the recent past. ${ }^{22}$, 25,34 The $\left\langle S^{2}\right\rangle$ values for the TS have typically shown minimal spin contamination, i.e., 0.81 $\left\langle\left\langle S^{2}\right\rangle<0.82\right.$. Conventional transition state theory (TST) was utilized to estimate the rates for spin-adduct formation at $298 \mathrm{~K} .{ }^{35}$ The conventional TST rate equation in the thermodynamic formulation as a function of temperature is as follows:

$$
k(T)_{T S T}=\Gamma(T) \frac{k_{B} T}{h} \exp \left(-\Delta G_{0}^{\ddagger} / k_{B} T\right)
$$

In Equation 1, $T$ is the absolute temperature, $h$ is Planck's constant, $k_{B}$ is Boltzmann constant, and $\Delta G^{\ddagger}{ }_{0}$ is the free energy barrier height relative to reactants at infinite separation. The temperature dependent factor $\Gamma(T)$ represents quantum mechanical tunneling and is accounted for by the Wigner approximation: ${ }^{36}$

$$
\Gamma(T)=1+\left(\frac{1}{24}\right)\left[1.44 \frac{v_{i}}{T}\right]^{2}
$$

in which $v_{i}$ is the imaginary vibrational frequency representing the TS barrier's curvature. 


\section{Results and Discussion}

\section{A. Nitrones and Hydroperoxyl Adducts}

Selected bond distances for the B3LYP/6-31G(d) optimized geometries of the nitrone spin traps and their corresponding $\mathrm{HO}_{2}{ }^{\circ}$ adducts are shown in Table $\mathrm{S} 1$ of the supporting information. All of the relevant bond distances for the nitrone and nitroxyl moieties as well as the various electron-withdrawing substituents are in good agreement with reported experimental X-ray crystallographic bond lengths for related compounds. 37

We previously 25 established, by a computational approach, that in aqueous solution, the amide functionality of AMPO, MAMPO, and DiMAPO (Chart 1) are predominantly in the amide form (or lactam form for TAMPO), rather than in the respective imidic acid (or lactim) form. Spin-adduct structures have $\mathrm{O}-\mathrm{O}$ bond distances from 1.41-1.42 $\AA$ in all of the $\mathrm{HO}_{2}{ }^{\circ}$ adducts. The $\mathrm{C}_{\text {ring }}-\mathrm{O}_{2} \mathrm{H}$ bond distances are in the $1.37-1.43 \AA$ range, similar to that observed experimentally for cyclic hydroperoxides $(\sim 1.46 \AA) .{ }^{38}$ The conformations for various $\mathrm{HO}_{2}{ }^{\bullet}$ adducts with nitrones obtained at the B3LYP/6-31G(d) level correlate well with those at the $\mathrm{mPW} 1 \mathrm{~K} / 6-31+\mathrm{G}(\mathrm{d}, \mathrm{p})$ level of theory (Table 1 ), with the exception of CPCOMPO- $\mathrm{O}_{2} \mathrm{H}$ in which the predicted O-O-C-N dihedral angle is smaller $\left(56.4^{\circ}\right)$ at the B3LYP/6-31G(d) level as compared to $\mathrm{mPW} 1 \mathrm{~K} / 6-31+\mathrm{G}(\mathrm{d}, \mathrm{p})\left(286.6^{\circ}\right)$. An $\mathrm{O}_{2} \mathrm{H}---\mathrm{O}-\mathrm{N}$ H-bonding interaction was observed for the $\mathrm{HO}_{2}{ }^{\circ}$ adducts of DiMAMPO, DiMAPO, DEPMPO, DMPO, TFMPO, MSMPO, CPPO, and EMPO, with an $\mathrm{H}---\mathrm{O}$ bond distances ranging from 2.04 to $3.09 \AA$. An $\mathrm{O}_{2} \mathrm{H}---\mathrm{O}=\mathrm{C} \mathrm{H}-$ bonding interaction was predicted for DEPO, CPCOMPO, and TAMPO with $\mathrm{H}---\mathrm{O}$ distances between 1.84 and $1.99 \AA$, while an $\mathrm{O}_{2} \mathrm{H}---\mathrm{NR}_{2}$ interaction was predicted for AMPO, MAMPO, and EMAPO with H---N distances of 2.30 to $2.42 \AA$. (See Figure S1 of the supplementary information for the $\mathrm{mPW} 1 \mathrm{~K} / 6-31+\mathrm{G}(\mathrm{d}, \mathrm{p})$ structural parameters.)

Figure 1 shows the most favored diastereomer $(2 S, 5 R)$ for the EMAPO- $\mathrm{O}_{2} \mathrm{H}$ adduct in which the amido group is trans to the $\mathrm{HO}_{2}$ moiety. The preferred $(2 S, 5 R)$ isomer for EMAPO- $\mathrm{O}_{2} \mathrm{H}$ exhibits two intramolecular H-bond interactions, (i.e., N-O---H-N and OOH---O-N) which are trans to each other and are more stable than the $(2 R, 5 R)$ isomer by $-0.6 \mathrm{kcal} / \mathrm{mol}$.

\section{B. Transition State Structures}

The TS structures for $\mathrm{HO}_{2}{ }^{\bullet}$ addition to the nitrones were calculated, and each stationary point gave a single imaginary vibrational frequency corresponding to motion along the $\mathrm{C}_{2}-\mathrm{O}_{2} \mathrm{H}$ bond axis (Table 2). The TSs for $\mathrm{HO}_{2}{ }^{\circ}$ addition have imaginary vibrational frequencies ranging from $323 i$ to $517 i \mathrm{~cm}^{-1}$ at the B3LYP/6-31G(d) level and $312 i$ to $411 i \mathrm{~cm}^{-1}$ at the mPW1K/6-31 $+\mathrm{G}(\mathrm{d}, \mathrm{p})$ level (Table 2).

The transition states have a narrow range of $\mathrm{C}_{2}---\mathrm{O}_{2} \mathrm{H}$ distances, ranging from 2.00-2.12 $\AA$ and $2.10-2.15 \AA$ at the B3LYP/6-31G(d) and mPW1K/6-31+G(d,p) levels, respectively. These calculated $\mathrm{C}_{2}---\mathrm{O}_{2} \mathrm{H}$ distances are intermediate between the distances calculated for the complexed form and the final adduct as a product (Table 2). The TS structures for $\mathrm{HO}_{2}{ }^{\bullet}$ addition have average sums of the bond angles around the $\mathrm{C}_{2}$ carbon of $356.6 \pm 1.0^{\circ}$; intermediate to those predicted for the nitrones $\left(360.0 \pm 0.1^{\circ}\right)$ and their respective $\mathrm{HO}_{2}{ }^{\circ}$ adduct products (328.1 $\left.\pm 1.2^{\circ}\right)$. In light of Hammond's postulate, the sums of the bond angles suggest that the TS for $\mathrm{HO}_{2}{ }^{\bullet}$ addition is early on the reaction coordinate; i.e., the TS structures are closer to the reactants.

Table 3 shows the spin density distribution for the various TS structures for $\mathrm{HO}_{2}{ }^{\bullet}$ addition at the B3LYP/6-31+G(d,p)//B3LYP/6-31G(d) and they are all very similar. The average spin densities (populations) on the nitronyl-N, nitronyl-O, hydroperoxyl- $\beta-\mathrm{O}$, and hydroperoxyl- $\gamma$ $\mathrm{O}$ atoms are $0.18 \pm 0.03,0.30 \pm 0.03,0.52 \pm 0.03$, and $0.17 \pm 0.02 \mathrm{e}$, respectively. The same trend has been observed at the $\mathrm{mPW} 1 \mathrm{~K} / 6-31+\mathrm{G}(\mathrm{d}, \mathrm{p})$ level (Table S8). The calculated spin 
densities for the $\mathrm{HO}_{2}{ }^{\circ}$ atoms are $0.73 \mathrm{e}$ for the distal $\mathrm{O}$ and $0.27 \mathrm{e}$ on the proximal $\mathrm{O}$ relative to $\mathrm{H}$, indicating that some electron transfer occurs from the $\mathrm{HO}_{2}{ }^{\circ}$ to the nitrone in the TS. We note that this behavior is contrary to the reaction of hydroxyl radical with electron-rich aromatic rings for which electron transfer from the aromatic unit is transferred to the hydroxyl moiety ${ }^{39} \mathrm{The}^{\mathrm{HO}}{ }_{2}{ }^{\circ}$ adduct structures show almost complete spin-population transfer to the nitroxyl moiety with spin densities of 0.43 e and 0.52 e on the nitroxyl $\mathrm{N}$ and $\mathrm{O}$, respectively.

The $\mathrm{OOH}---\mathrm{O}=\mathrm{C}, \mathrm{OOH}---\mathrm{NR}_{2}$, and $\mathrm{OOH}---\mathrm{O}-\mathrm{N}$ H-bond distances in the transition states are very similar to $\mathrm{H}$-bond distances observed in their respective product structures with deviations of $0.1-0.3 \AA$ (Figure S1). These predicted interactions play a significant role in stabilizing the TS structures, and hence, in the facile formation of the adducts as products. All predicted TS H-bonding interactions are present for both $\mathrm{B} 3 \mathrm{LYP} / 6-31 \mathrm{G}(\mathrm{d})$ and $\mathrm{mPW} 1 \mathrm{~K} / 6-31+\mathrm{G}(\mathrm{d}, \mathrm{p})$ optimized structures.

\section{Calculated Bimolecular Rate Constants}

In our previously studies, 11,40 we showed that the direct addition of $\mathrm{HO}_{2}{ }^{\bullet}$ to DMPO is one of the two possible mechanisms for the formation of DMPO- $\mathrm{O}_{2} \mathrm{H}$ in aqueous solution with $\mathrm{O}_{2}{ }^{-}$ addition followed by proton transfer being the other. This reaction is relevant since the generation of $\mathrm{O}_{2}{ }^{-\bullet}$ in acidic condition can favor direct radical addition of $\mathrm{HO}_{2}{ }^{\bullet}$ instead of $\mathrm{O}_{2}{ }^{\bullet-}$ to DMPO. The free energies for $\mathrm{O}_{2}{ }^{\bullet-}$ protonation by hydronium ion in an aqueous medium is highly exoergic; $\Delta G_{\mathrm{rxn}-1, \mathrm{aq}}=-41.1$ and $-40.5 \mathrm{kcal} / \mathrm{mol}$ at the $\mathrm{PCM} / \mathrm{mPW} 1 \mathrm{~K} / 6-31+\mathrm{G}(\mathrm{d}, \mathrm{p})$ and PCM/B3LYP/6-31+G(d,p)//B3LYP/6-31G(d) levels, respectively (see Table 4).

Reactions for $\mathrm{HO}_{2}{ }^{\circ}$ addition to nitrones are exoergic with $\Delta G_{\mathrm{rxn}-2, \text { aq }}$ (Table 4) values that range from -5.1 to $-11.5 \mathrm{kcal} / \mathrm{mol}$, while $\mathrm{O}_{2}{ }^{-}$additions to nitrones are endoergic with $\Delta G_{\mathrm{aq}}=0.7$ to $8.3 \mathrm{kcal} / \mathrm{mol}$ at the $\mathrm{PCM} / \mathrm{mPW} 1 \mathrm{~K} / 6-31+\mathrm{G}(\mathrm{d}, \mathrm{p})$ level. ${ }^{25}$ These free energies of reaction are consistent with the experimental reduction potentials of $E^{\mathrm{o}}=1.06$ and $0.94 \mathrm{~V}$ for $\mathrm{HO}_{2}{ }^{\circ}$ and $\mathrm{O}_{2}{ }^{\circ}$, respectively. ${ }^{41}$ The free energies of reaction for $\mathrm{HO}_{2}{ }^{\bullet}$ reactions with nitrones follow the order of increasing (more positive) $\Delta G_{\text {rxn }}$ (in kcal $/ \mathrm{mol}$ ): $\operatorname{MSMPO}(-10.2)>\operatorname{DEPO}(-10.1)>$ EMPO $(-9.5)>$ TFMPO $(-9.4)>$ DiMAMPO $(-8.9)>$ CPCOMPO $(-8.7)>$ DEPMPO $(-8.6)$ $>\mathrm{TAMPO}=\mathrm{CPPO}(-8.5)>\mathrm{DMPO}(-8.2)>$ EMAPO trans addition to amide group $(-8.0)>$ DiMAPO (-5.6) > AMPO (-5.5) > MAMPO = EMAPO cis addition to amide group (5.1) and the $N$-monoalkylamide substituted nitrones MAMPO, DiMAPO, and EMAPO (Table 4). In contrast to the predicted thermodynamics for the $\mathrm{O}_{2}{ }^{--}$additions to amide-substituted nitrones which is the most favorable, the $\mathrm{HO}_{2}{ }^{\circ}$ additions to $N$-monoalkylamide substituted nitrones were not the most thermodynamically favored. 25

At the $\mathrm{PCM} / \mathrm{mPW} 1 \mathrm{~K} / 6-31+\mathrm{G}(\mathrm{d}, \mathrm{p}) / / \mathrm{mPW} 1 \mathrm{~K} / 6-31+\mathrm{G}(\mathrm{d}, \mathrm{p})$ level, the calculated rate constants, $k_{\mathrm{rxn}-2}$, for $\mathrm{HO}_{2}{ }^{\bullet}$ addition to nitrones are the greatest for DEPO $\left(k_{\mathrm{rxn}-2}=3.0 \times 10^{3}\right.$ $\left.M^{-1} \mathrm{~s}^{-1}\right)$ followed by TAMPO $\left(k_{\mathrm{rxn}-2}=1.9 \times 10^{3} M^{-1} \mathrm{~s}^{-1}\right)$, trans addition to the amide moiety of EMAPO $\left(k_{\mathrm{rxn}-2}=1.4 \times 10^{3} M^{-1} \mathrm{~s}^{-1}\right)$, EMPO $\left(k_{\mathrm{rxn}-2}=1.5 \times 10^{3} M^{-1} \mathrm{~s}^{-1}\right)$, CPPO $\left(k_{\mathrm{rxn}-2}=\right.$ $\left.1.1 \times 10^{3} \mathrm{M}^{-1} \mathrm{~s}^{-1}\right)$ and DMPO $\left(k_{\mathrm{rxn}-2}=1.0 \times 10^{3} \mathrm{M}^{-1} \mathrm{~s}^{-1}\right)$. The TFMPO, DEPMPO and MSMPO nitrones have intermediate rate constants with values $k_{\mathrm{rxn}-2}=276.0,125.8$ and 105.9 $M^{-1} \mathrm{~s}^{-1}$, respectively. The nitrones that have the smallest rate constants for $\mathrm{HO}_{2}{ }^{\bullet}$ addition are the amide-nitrones, i.e., AMPO, MAMPO, DiMAMPO, DiMAPO, and EMAPO (where the $\mathrm{HO}_{2}{ }^{\circ}$ addition is cis to the amide group), as well as CPCOMPO where the rate constants are in the range 1.3 to $61.9 \mathrm{M}^{-1} \mathrm{~s}^{-1}$ (see Table 4). The same qualitative trend is predicted at the PCM/B3LYP/6-31+G(d,p)//B3LYP/6-31G(d) level, with the exception of DEPMPO.

The electronic and thermodynamic parameters including the $\mathrm{C}_{2}$ charge densities, rate constants, free energies, electron affinities and ionization potentials calculated at the PCM/ $\mathrm{mPW} 1 \mathrm{~K} / 6-31+\mathrm{G}(\mathrm{d}, \mathrm{p}) / / \mathrm{mPW} 1 \mathrm{~K} / 6-31+\mathrm{G}(\mathrm{d}, \mathrm{p})$ level correlate well with those calculated at the PCM/B3LYP/6-31+G(d,p)//B3LYP/6-31G(d) level of theory as shown in the Figure S2 of 
the supplementary information. However, the preference for $\mathrm{HO}_{2}{ }^{\bullet}$ addition to certain nitrones does not follow the same trend observed for $\mathrm{O}_{2}{ }^{--}$addition that we reported recently 25 in which we demonstrated a dependence of $k_{\mathrm{rxn}-2}$ and $\Delta G_{\mathrm{rxn}-2}$ on the $\mathrm{C}_{2}$ charge density of the nitrone. The PCM/mPW1K/6-31+G(d,p)//mPW1K/6-31+G(d,p) $k_{\mathrm{rxn}-2}$ and $\Delta G_{\mathrm{rxn}-2}$ values for $\mathrm{HO}_{2}{ }^{*}$ addition to nitrones give a poor correlation with nitrone $\mathrm{C}_{2}$ charge densities (see Figures S3a and S3b). Poor correlation also resulted from the PCM/B3LYP/6 $-31+\mathrm{G}(\mathrm{d}, \mathrm{p}) / / \mathrm{B} 3 \mathrm{LY} / \mathrm{6}-31 \mathrm{G}$ (d) values (see Figure $\mathrm{S} 4 \mathrm{a}$ and $\mathrm{S} 4 \mathrm{~b}$ ). The poor correlation between the $\mathrm{C}_{2}$ charge densities and the favorability of $\mathrm{HO}_{2}{ }^{\circ}$ addition to nitrones suggests that electrostatic effects play a minor role in these $\mathrm{HO}_{2}{ }^{\circ}$ reactions.

In general, the magnitude of $k_{\mathrm{rxn}-2}$, which is in the order of 1 to $10^{3} \mathrm{M}^{-1} \mathrm{~s}^{-1}$, agrees well with the bimolecular rate constants observed experimentally in acidic solutions for the spin trapping of $\mathrm{O}_{2}{ }^{\circ}$ by nitrones. ${ }^{20,42}$ However, a plausible explanation for the difference in nucleophilicity between $\mathrm{HO}_{2}{ }^{\bullet}$ and $\mathrm{O}_{2}{ }^{-}$is that although both are $\pi$-type radicals, their spin and charge density distributions are not very similar. For example, the spin density distribution and charge density on the attacking atom are $73 \%$ and -0.15 e for $\mathrm{HO}_{2}{ }^{\circ}$ and $50 \%$ and -0.50 e for $\mathrm{O}_{2}{ }^{\circ}$, respectively. Based on the lower negative charge density and higher electron density distribution on the terminal $\mathrm{O}$ in $\mathrm{HO}_{2}{ }^{\circ}$ compared to $\mathrm{O}_{2}{ }^{--}$, the nature of $\mathrm{HO}_{2}{ }^{\circ}$ radical addition to $\mathrm{C}=\mathrm{N}$ of the nitrones can be predicted to be mostly electrophilic in nature rather than nucleophilic. Also, the presence of a low-lying first electronic excited state in $\mathrm{HO}_{2}{ }^{\circ}$ can play a major role in determining the rate of its addition to nitrones; as observed in $\mathrm{HO}_{2}{ }^{\circ}$ reactions with some olefins. ${ }^{43}$

To further evaluate if a charge-transfer mechanism was playing a role in determining the rate of $\mathrm{HO}_{2}{ }^{\bullet}$ addition to nitrones, the electron affinities (EA) and ionization potentials (IP) for the nitrones were calculated at the $\mathrm{PCM} / \mathrm{mPW} 1 \mathrm{~K} / 6-31+\mathrm{G}(\mathrm{d}, \mathrm{p}) / / \mathrm{mPW} 1 \mathrm{~K} / 6-31+\mathrm{G}(\mathrm{d}, \mathrm{p})$ and $\mathrm{PCM} /$ B3LYP/6-31+G(d,p)//B3LYP/6-31G(d) levels (Table 4). However, results show that there is no correlation between the calculated $\Delta G_{\mathrm{rxn}-2}$ or $k_{\mathrm{rxn}-2}$ with the theoretical EA and IP values of these nitrones (see Figure S5-S8). The same trend was observed using gas-phase energies at both levels of theory. The poor correlation between the rate constants and thermodynamic values could be due to the presence of H-bonding in the transition states that can bias the energies of the TS structures and this is further discussed below.

Unlike in the $\mathrm{O}_{2}{ }^{-}$addition reactions, ${ }^{25}$ a rationale for the trends observed for $\mathrm{HO}_{2}{ }^{\bullet}$ addition favorability to some nitrones cannot be established based on calculated energies, rate constants, or electron-transfer mechanisms versus the charge density on $\mathrm{C}_{2}$. However, there is a direct relationship between the kinetic parameters and strong H-bond interactions between the hydroperoxyl-H and the carbonyl-O in the TS structures which improve adduct formation; although the $\mathrm{C}_{2}-\mathrm{O}_{2} \mathrm{H}$ distances in all the TS structures are almost the same $(\sim 2.1 \AA)$. For example, at the mPW1K/6-31+G(d,p) level, EMAPO, DEPO, TAMPO, and CPCOMPO have strong interactions yielding $\mathrm{OOH}---\mathrm{O}=\mathrm{C}$ distance from 1.76 to $1.87 \AA$. The other adducts have $\mathrm{OOH}---\mathrm{NR}_{2}$ and $\mathrm{OOH}---\mathrm{O}-\mathrm{N}$ distances in the range of $2.07-2.42 \AA$. The high $k_{\mathrm{rxn}-2}$ value observed for EMPO cannot be rationalized in terms of strong H-bonding in the TS since the OOH---O-N distance observed was only $2.27 \AA$, while CPCOMPO has stronger interactions yielding a $\mathrm{OOH}---\mathrm{O}=\mathrm{C}$ distance of $1.83 \AA$, but only gave a relatively small $k_{\mathrm{rxn}-2}$ value of 61.9 $M^{-1} \mathrm{~s}^{-1}$. Considering that the charge densities for CPCOMPO and EMPO are quite similar $(\sim 0.04 \mathrm{e})$, the difference in their reactivity could not be explained in terms of charge density on the $\mathrm{C}_{2}$, electron affinity or the presence of $\mathrm{H}$-bonding in the TS.

\section{Conclusions}

The reactivity of $\mathrm{HO}_{2}{ }^{\bullet}$ toward various nitrones has been assessed from theoretical free energies of reaction, bimolecular rate constants, spin and charge densities, and hydrogen-bonding interactions. The calculated rate constants are on the same order of magnitude as those observed 
experimentally for spin trapping in acidic aqueous solutions (i.e., $\sim 10^{2}$ to $10^{3} M^{-1} \mathrm{~s}^{-1}$ ). The transition state structures for $\mathrm{HO}_{2}{ }^{\bullet}$ addition to the various nitrones are relatively early on the potential energy surface as evidenced by the minor distortion of the bond angles around the nitronyl-C in the transition states. However, theoretically derived kinetic and thermodynamic parameters provide poor correlations with the calculated charge densities on the nitronyl-C $\left(\mathrm{C}_{2}\right.$, the site of radical addition) contrary to that observed for the reactivity of $\mathrm{O}_{2}{ }^{\circ-}$ to nitrones; 25 an indication that the $\mathrm{HO}_{2}{ }^{\circ}$ addition to nitrones is not nucleophilic in nature. Strong $\mathrm{H}$ bonding interactions between the hydroperoxyl- $\mathrm{H}$ and the carbonyl-O in the TS for some reactions play a significant role in facilitating $\mathrm{HO}_{2}{ }^{-}$addition to nitrones. This observation suggests a need for strong $\mathrm{H}$-bond acceptors in the design of nitrone-based antioxidants and spin traps for efficient $\mathrm{HO}_{2}{ }^{\bullet}$ scavenging in biological systems.

\section{Supplementary Material}

Refer to Web version on PubMed Central for supplementary material.

\section{Acknowledgments}

This work is supported by NIH grant HL081248. JLZ acknowledges support from the NIH grants HL38324, HL63744 and HL65608. CMH acknowledges support from the NSF-funded Environmental Molecular Science Institute (CHE-0089147). The Ohio Supercomputer Center (OSC) is acknowledged for generous computational support of this research.

\section{References}

1. Halliwell B. Oxidative Stress and Disease 2001;7:1-16.Halliwell B. Drugs \& Aging 2001;18:685716. [PubMed: 11599635]Zweier JL, Talukder MAH. Cardiovascular Research 2006;70:181-190. [PubMed: 16580655]Zweier, JL.; Villamena, FA. Oxidative Stress and Cardiac Failure. Kukin, ML.; Fuster, V., editors. Futura Publishing; Armonk, N. Y.: 2003. p. 67-95.

2. Sawyer DT, Chlerlcato JG, Angells CT, Nannl J,EJ, Tsuchlya T. Anal. Chem 1982;1082:1720-1724.

3. Behar D, Czapski G, Rabani J, Dorfman LM, Schwarz HA. J. Phys. Chem 1970;74:3209-3213.

4. Czapski G, Bielski BHJ. J. Phys. Chem 1963;67:2180-2184.

5. Halliwell, B.; Gutteridge, JMC. Free Radicals in Biology and Medicine. Oxford University Press; New York: 1999.

6. Cheng, Z. a. L., Y. Chem. Rev 2007;107:748-766. [PubMed: 17326688]

7. Zweier JL, Broderick R, Kuppusamy P, Thompson-Gorman S, Lutty GA. J. Biol. Chem 1994;269:24156-62. [PubMed: 7929072]

8. Zweier JL, Flaherty JT, Weisfeldt ML. Proc. Natl. Acad. U.S.A 1987;84:1404.Zweier JL, Kuppusamy P, Lutty GA. Proc. Natl. Acad. U.S.A 1988;85:4046.Zweier JL, Kuppusamy P, Williams R, Rayburn BK, Smith D, Weisfeldt ML, Flaherty JT. J. Biol. Chem 1989;264:18890. [PubMed: 2553726]

9. Ambrosio G, Zweier JL, Flaherty JT. J. Mol. Cell Cardiol 1991;23:1359-74. [PubMed: 1811055]

10. Janzen EG. Free Radical Biol. Med 1980;4:115-154.Janzen EG. Acc. Chem. Res 1971;4:3140.Janzen EG, Haire DL. Adv. Free Radical Chem 1990;1:253-295.Rhodes, CJ., editor. Toxicology of the Human Environment. The Critical Role of Free Radicals. Taylor and Francis; London: 2000. Rosen, GM.; Britigan, BE.; Halpern, HJ.; Pou, S. Free Radicals: Biology and Detection by Spin Trapping. Oxford University Press; New York: 1999. Villamena FA, Zweier JL. Antioxid. Redox Signaling 2004;6:619-629.

11. Villamena FA, Merle JK, Hadad CM, Zweier JL. J. Phys. Chem. A 2005;109:6083-6088. [PubMed: 16833945]

12. Nonogawa M, Arai T, Endo N, Pack SP, Kodaki T, Makino K. Org. Biomol. Chem 2006;4:18111816. [PubMed: 16633574]Zhang H, Joseph J, Vasquez-Vivar J, Karoui H, Nsanzumuhire C, Martasek P, Tordo P, Kalyanaraman B. FEBS Lett 2000;473:58-62. [PubMed: 10802059]

13. Breuer, E.; Aurich, HG.; Nielsen, A. Nitrones, Nitronates and Nitroxides. John Wiley and Sons; New York: 1989. 
14. Floyd RA. Aging Cell 2006;5:51-57. [PubMed: 16441843]Nakae D, Kishida H, Enami T, Konishi Y, Hensley KL, Floyd RA, Kotake Y. Cancer Science 2003;94:26-31. [PubMed: 12708470]Nakae D, Uematsu F, Kishida H, Kusuoka O, Katsuda S.-i. Yoshida M, Takahashi M, Maekawa A, Denda A, Konishi Y, Kotake Y, Floyd RA. Cancer Letters (Amsterdam, Netherlands) 2004;206:113.Becker DA, Ley JJ, Echegoyen L, Alvarado R. J. Am. Chem. Soc 2002;124:4678. [PubMed: 11971716]Ginsberg MD, Becker DA, Busto R, Belayev A, Zhang Y, Khoutorova L, Ley JJ, Zhao W, Belayev L. Annals of Neurology 2003;54:330. [PubMed: 12953265]

15. Floyd RA, Hensley K. Ann. New York Acad. Sci 2000;899:222-237. [PubMed: 10863542]

16. Packer, L.; Cadenas, E., editors. Handbook of Synthetic Antioxidants. Marcel Dekker, Inc.; New York: 1997.

17. Fong JJ, Rhoney DH. Annals of Pharmacotherapy 2006;40:461-471. [PubMed: 16507608]Maples KR, Green AR, Floyd RA. CNS Drugs 2004;18:1071-1084. [PubMed: 15581379]Zhao Z, Cheng M, Maples KR, Ma JY, Buchan AM. Brain Research 2001;909:46-50. [PubMed: 11478919]

18. Konorev EA, Baker JE, Joseph J, Kalyanaraman B. Free Radic. Biol. Med 1993;14:127-37. [PubMed: 8425719]Pietri S, Liebgott T, Frijaville C, Tordo P, Culcasi M. Eur. J. Biochem 1998;254:256-265. [PubMed: 9660178]

19. Lapchak PA, Araujo DM, Song D, Wei J, Purdy R, Zivin JA. Stroke 2002;33:1665-1670. [PubMed: 12053009]Tosaki A, Blasig IE, Pali T, Ebert B. Free Radic. Biol. Med 1990;8:363-72. [PubMed: 2165975]

20. Finkelstein E, Rosen GM, Rauckman EJ. J. Am. Chem. Soc 1980;102:4995.

21. Boyd SL, Boyd RJ. J. Phys. Chem 1994;98:11705-11713.

22. Villamena FA, Hadad CM, Zweier JL. J. Phys. Chem. A 2005;109:1662-1674. [PubMed: 16833491]

23. Bosnjakovic A, Schlick S. Journal of Physical Chemistry B 2006;110:10720-10728.Panchenko A, Dilger H, Kerres J, Hein M, Ullrich A, Kaz T, Roduner E. Phys. Chem. Chem. Phys 2004;6:28912894.Yang J, Chen C, Ji H, Ma W, Zhao J. J. Phys. Chem. B 2005;109:21900-21907. [PubMed: 16853845]Yu J, Chen J, Li C, Wang X, Zhang B, Ding H. Journal of Physical Chemistry B 2004;108:2781-2783. Vakrat-Haglili Y, Weiner L, Brumfeld V, Brandis A, Salomon Y, McLlroy B, Wilson BC, Pawlak A, Rozanowska M, Sarna T, Scherz A. J. Am. Chem. Soc 2005;127:6487-6497. [PubMed: 15853357]Nam S-N, Han S-K, Kang JW, Choi H. Ultrasonics Sonochem 2003;10:39_ 147.Balakirev MY, Khramtsov VV. J. Org. Chem 1996;61:7263-7269. [PubMed: 11667648]

24. Chen Y-R, Chen C-L, Yeh A, Liu X, Zweier JL. Journal of Biological Chemistry 2006;281:1315913168. [PubMed: 16531408]Dugan LL, Sensi SL, Canzoniero LMT, Handran SD, Rothman SM, Lin TS, Goldberg MP, Choi DW. J. of Neuroscience 1995;15:6377-88.Partridge RS, Monroe SM, Parks JK, Johnson K, Parker WD Jr. Eaton GR, Eaton SS. Archives of Biochemistry and Biophysics 1994;310:210-17. [PubMed: 8161207]Nohl H, Jordan W, Hegner D. FEBS Letters 1981;123:2414. [PubMed: 6262109]Wang P, Chen H, Qin H, Sankarapandi S, Becher MW, Wong PC, Zweier JL. Proc. Natl. Acad. Sci. U S A 1998;95:4556-60. [PubMed: 9539776]

25. Villamena FA, Xia S, Merle JK, Lauricella R, Tuccio B, Hadad CM, Zweier JL. J. Am. Chem. Soc 2007;129:8177-8191. [PubMed: 17564447]

26. Frisch, MJ., et al. Gaussian, Inc.; Pittsburgh PA: 2002. Revision A.11.3 ed.

27. Labanowski, JW.; Andzelm, J. Density Functional Methods in Chemistry. Springer; New York: 1991. Parr, RG.; Yang, W. Density Functional Theory in Atoms and Molecules. Oxford University Press; New York: 1989.

28. Becke AD. Phys. Rev 1988;38:3098-3100.Lee C, Yang W, Parr RG. Phys. Rev. B 1988;37:785789.Becke AD. J. Chem. Phys 1993;98:1372-7.Hehre, WJ.; Radom, L.; Schleyer, PV.; Pople, JA. Ab Initio Molecular Orbital Theory. John Wiley \& Sons; New York: 1986.

29. Lynch BJ, Fast PL, Harris M, Truhlar DG. J. Phys. Chem. A 2000;104:4811.

30. Tomasi J, Persico M. Chem. Rev 1994;94:2027-94.Cossi M, Barone V, Cammi R, Tomasi J. Chem. Phys. Lett 1996;255:327-335.Barone V, Cossi M, Tomasi J. J. Chem. Phys 1997;107:3210.Barone V, Cossi M, Tomasi J. J. Comput. Chem 1998;19:404.Cossi M, Barone V. J. Chem. Phys 1998;109:6246.

31. Scott AP, Radom L. J. Phys. Chem 1996;100:16502-16513.

32. Lynch BJ, Truhlar DG. J. Phys. Chem. A 2001;105:2936.

33. Reed AE, Curtiss LA, Weinhold FA. Chem. Rev 1988;88:899-926. 
34. Barckholtz C, Barckholtz TA, Hadad CM. J. Phys. Chem. A 2001;105:140-15.

35. Laidler, KJ. Chemical Kinetics. Harper \& Row, Publishers, Inc.; New York: 1987.

36. Wigner EPZ. Phys. Chem. Abt. B 1932;19:203.

37. Villamena F, Dickman MH, Crist DR. Inorg. Chem 1998;37:1446-1453.Boeyens JCA, Kruger GJ. Acta Cryst 1970;B26:668.Xu YK, Chen ZW, Sun J, Liu K, Chen W, Shi W, Wang HM, Zhang XK, Liu Y. J. Org. Chem 2002;67:7624-7630. [PubMed: 12398482]

38. Alini S, Citterio A, Farina A, Fochi MC, Malpezzi L. Acta Cryst 1998;C54:1000-1003.

39. DeMatteo M, Poole JS, Shi X, Sachdeva R, Hatcher P, Hadad CM, Platz MS. J. Am. Chem. Soc 2005;127:7094-7109. [PubMed: 15884952]

40. Villamena FA, Rockenbauer A, Gallucci J, Velayutham M, Hadad CM, Zweier JL. J. Org. Chem 2004;69:7994-8004. [PubMed: 15527282]

41. Buettner GR. Arch. Biochem. Biophys 1993;300:535-543. [PubMed: 8434935]

42. Tsai P, Ichikawa K, Mailer C, Pou S, Halpern HJ, Robinson BH, Nielsen R, Rosen GM. J. Org. Chem 2003;68:7811-7817. [PubMed: 14510560]

43. Stark MS. J. Am. Chem. Soc 2000;122:4162-4170.Stark MS. J. Phys Chem. A 1997;101:8296-8301. 44. Clifford EP, Wenthold PGG,R, Lineberger WC, DePuy CH, Bierbaum VM, Ellison GB. J. Chem. Phys 1998;109 


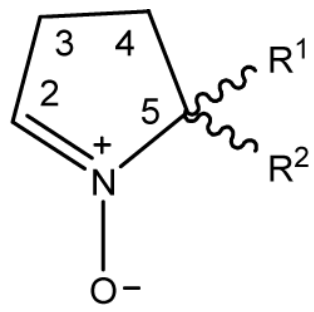

$\mathrm{R}^{1}$

$-\mathrm{CH}_{3}$

$-\mathrm{CH}_{3}$

$-\mathrm{CH}_{3}$

$-\mathrm{CH}_{3}$

$-\mathrm{CH}_{3}$

$-\mathrm{CH}_{3}$

$-\mathrm{CH}_{3}$

$-\mathrm{CO}_{2} \mathrm{Et}$

$-\mathrm{CO}_{2} \mathrm{Et}$

$-\mathrm{C}(\mathrm{O}) \mathrm{NHCH}_{3}$
$\mathrm{R}^{2}$

$-\mathrm{CH}_{3}$

$-\mathrm{CF}_{3}$

$-\mathrm{C}(\mathrm{O}) \mathrm{NH}_{2}$

$-\mathrm{C}(\mathrm{O}) \mathrm{NHCH}_{3} \quad \mathrm{MAMPO}$

$-\mathrm{C}(\mathrm{O}) \mathrm{N}\left(\mathrm{CH}_{3}\right)_{2}$ DiMAMPO

$-\mathrm{CO}_{2} \mathrm{Et}$

$-\mathrm{P}(\mathrm{O})(\mathrm{OEt})_{2} \quad$ DEPMPO

$-\mathrm{CO}_{2} \mathrm{Et}$

$-\mathrm{C}(\mathrm{O}) \mathrm{NHCH}_{3}$ EMAPO

$-\mathrm{C}(\mathrm{O}) \mathrm{NHCH}_{3}$ DiMAPO

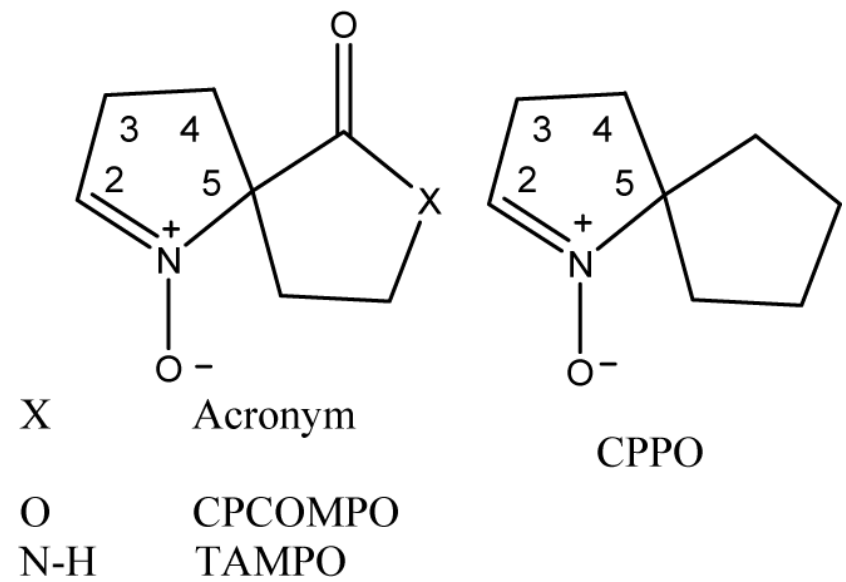

Chart 1.

DMPO-type nitrones used to theoretically investigate spin trapping of hydroperoxyl radical. 

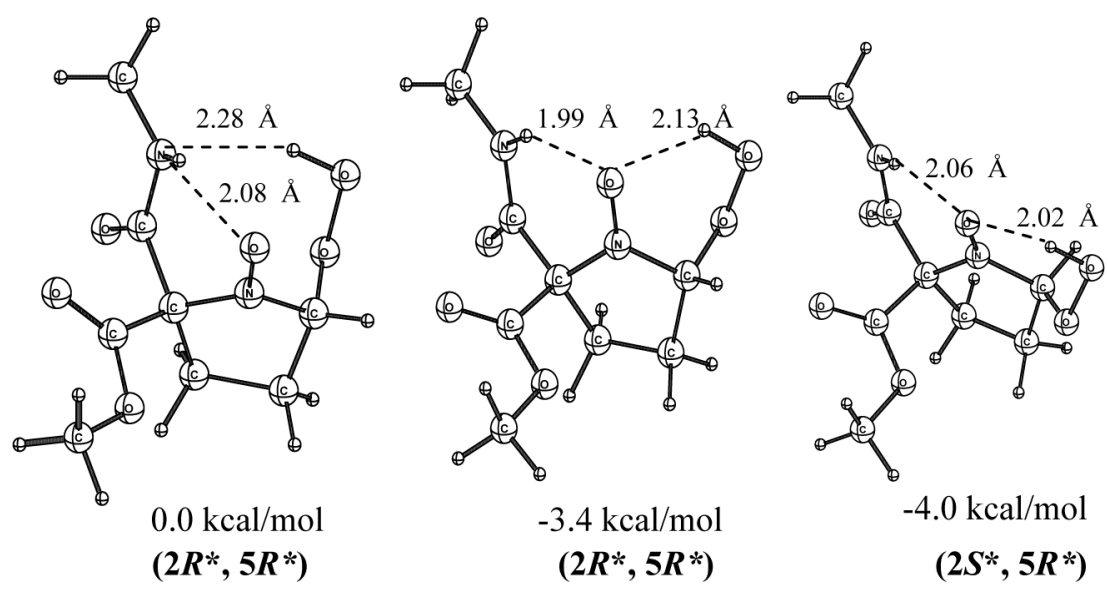

Figure 1.

Relative free energies in aqueous solution $\left(G_{298 \mathrm{~K} \text {, aq }}\right.$ in $\left.\mathrm{kcal} / \mathrm{mol}\right)$ of various optimized EMAPO $\mathrm{HO}_{2}{ }^{\bullet}$ adducts showing strong intramolecular interactions at the PCM/B3LYP/6-31+G(d,p)// B3LYP/6-31G(d) level. Note that the preferred isomer is $\left(2 S^{*}, 5 R^{*}\right)-\mathrm{EMAPO}-\mathrm{O}_{2} \mathrm{H}$ in which the hydroperoxyl moiety is trans to the amide group. 
Table 1

Hydroperoxide nitrone adduct OOCN dihedral angles for the B3LYP/6-31G(d) and mPW1K/6-31+G(d,p) (in parentheses) structures.

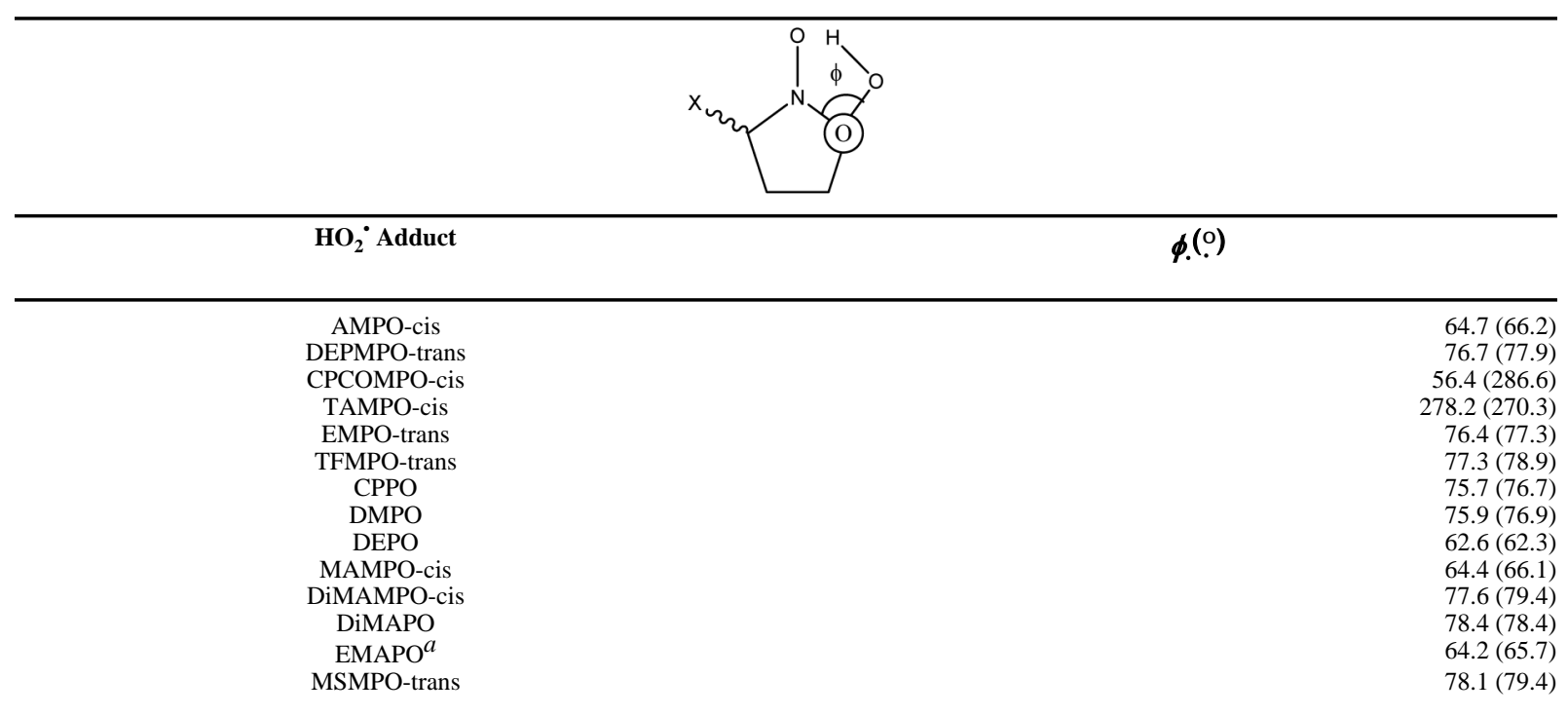

\footnotetext{
${ }^{a}$ Where-OOH group is $c$ is to the amide group.
} 


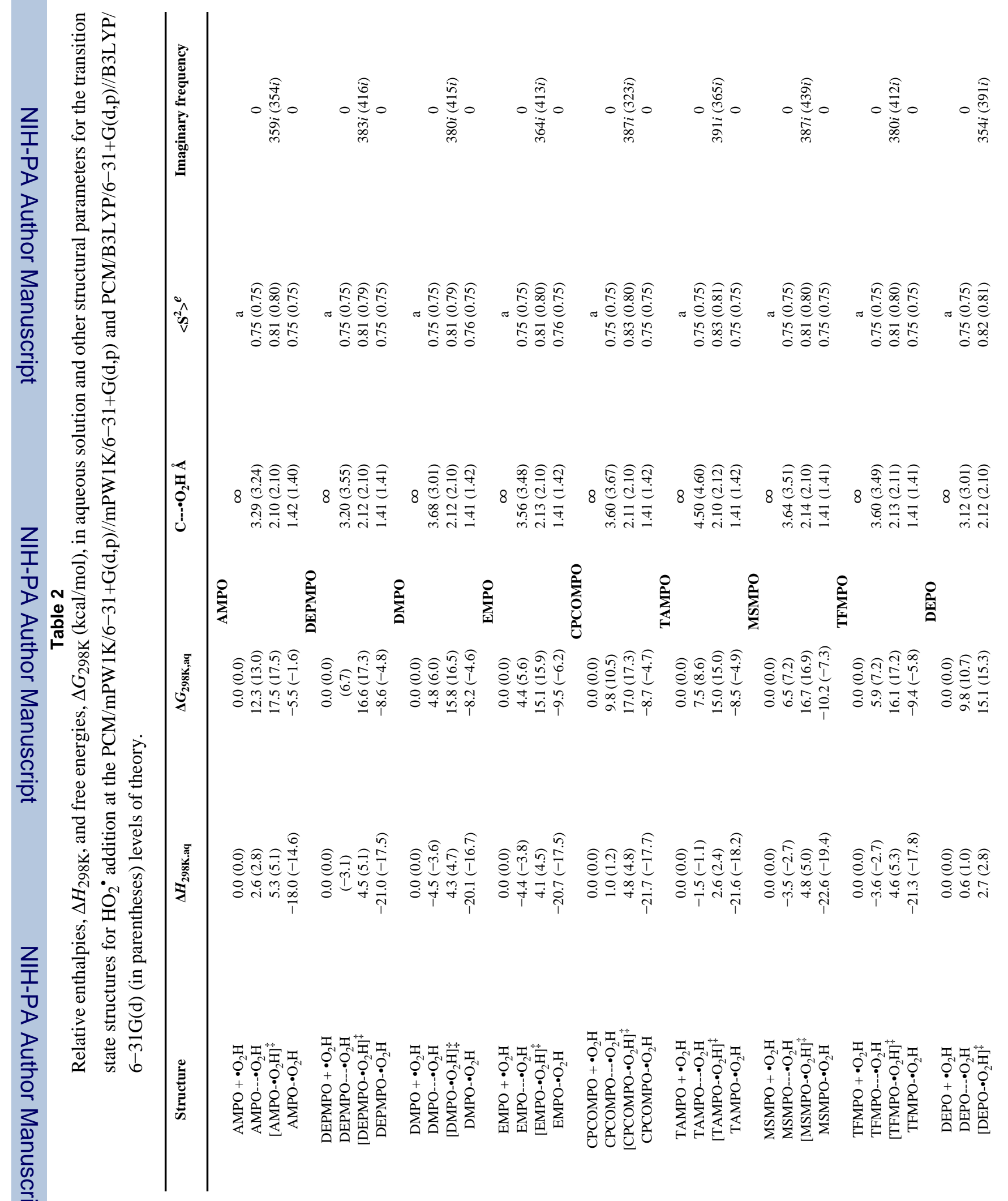




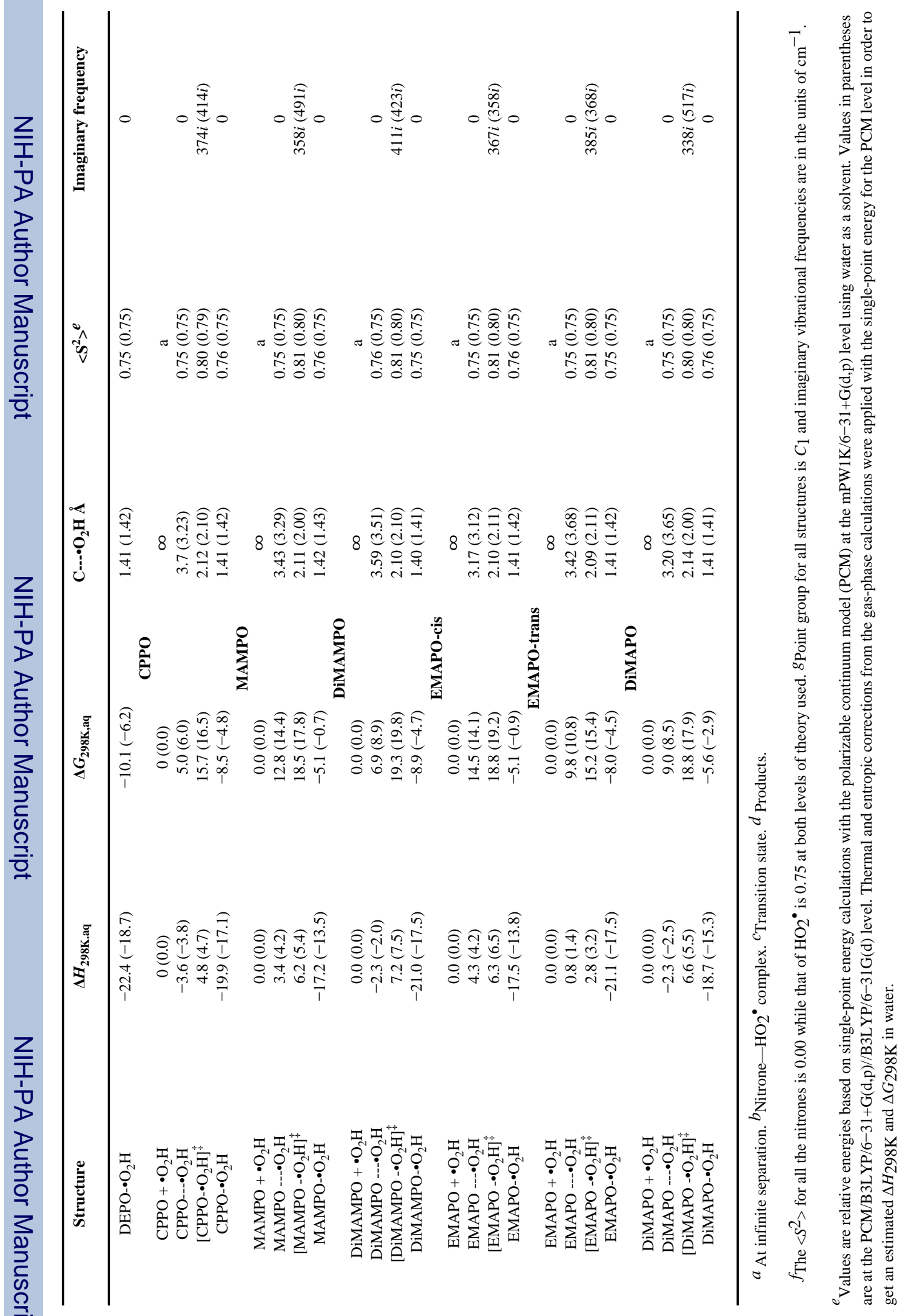


Table 3

NPA Charges and Spin Densities (Populations) of Transition States for the formation of various Hydroperoxyl Adducts at the B3LYP/6-31+G**//B3LYP/6-31G* level, in units of electrons.

\begin{tabular}{|c|c|c|c|c|}
\hline & $\mathbf{N}$ & $O_{\text {nitroxyl }}$ & $\beta-O$ & $\gamma-0$ \\
\hline AMPO & $0.02,0.17$ & $-0.50,0.28$ & $-0.26,0.53$ & $-0.41,0.18$ \\
\hline DEPMPO & $0.02,0.19$ & $-0.51,0.27$ & $-0.26,0.53$ & $-0.42,0.16$ \\
\hline DMPO & $0.04,0.18$ & $-0.50,0.28$ & $-0.27,0.53$ & $-0.43,0.15$ \\
\hline EMPO & $0.04,0.18$ & $-0.49,0.29$ & $-0.27,0.53$ & $-0.43,0.16$ \\
\hline СРCOMPO & $0.04,0.16$ & $-0.47,0.29$ & $-0.28,0.54$ & $-0.40,0.19$ \\
\hline TAMPO & $0.04,0.18$ & $-0.47,0.31$ & $-0.25,0.53$ & $-0.43,0.17$ \\
\hline MSMPO & $0.01,0.18$ & $-0.47,0.31$ & $-0.27,0.52$ & $-0.42,0.16$ \\
\hline TFMPO & $0.03,0.17$ & $-0.48,0.29$ & $-0.26,0.54$ & $-0.42,0.17$ \\
\hline DEPO & $0.03,0.15$ & $-0.44,0.33$ & $-0.28,0.51$ & $-0.41,0.19$ \\
\hline СРPO & $0.04,0.19$ & $-0.51,0.27$ & $-0.26,0.53$ & $-0.43,0.16$ \\
\hline MSMPO & $0.01,0.18$ & $-0.47,0.31$ & $-0.27,0.52$ & $-0.42,0.16$ \\
\hline MAMPO & $0.01,0.22$ & $-0.46,0.37$ & $-0.29,0.44$ & $-0.44,0.13$ \\
\hline DiMAMPO & $0.03,0.19$ & $-0.51,0.26$ & $-0.25,0.55$ & $-0.43,0.16$ \\
\hline DiMAPO & $0.03,0.26$ & $-0.47,0.36$ & $-0.28,0.43$ & $-0.44,0.11$ \\
\hline EMAPO cis & $0.03,0.16$ & $-0.49,0.28$ & $-0.26,0.53$ & $-0.40,0.19$ \\
\hline EMAPO trans & $0.02,0.17$ & $-0.49,0.28$ & $-0.26,0.53$ & $-0.40,0.20$ \\
\hline
\end{tabular}




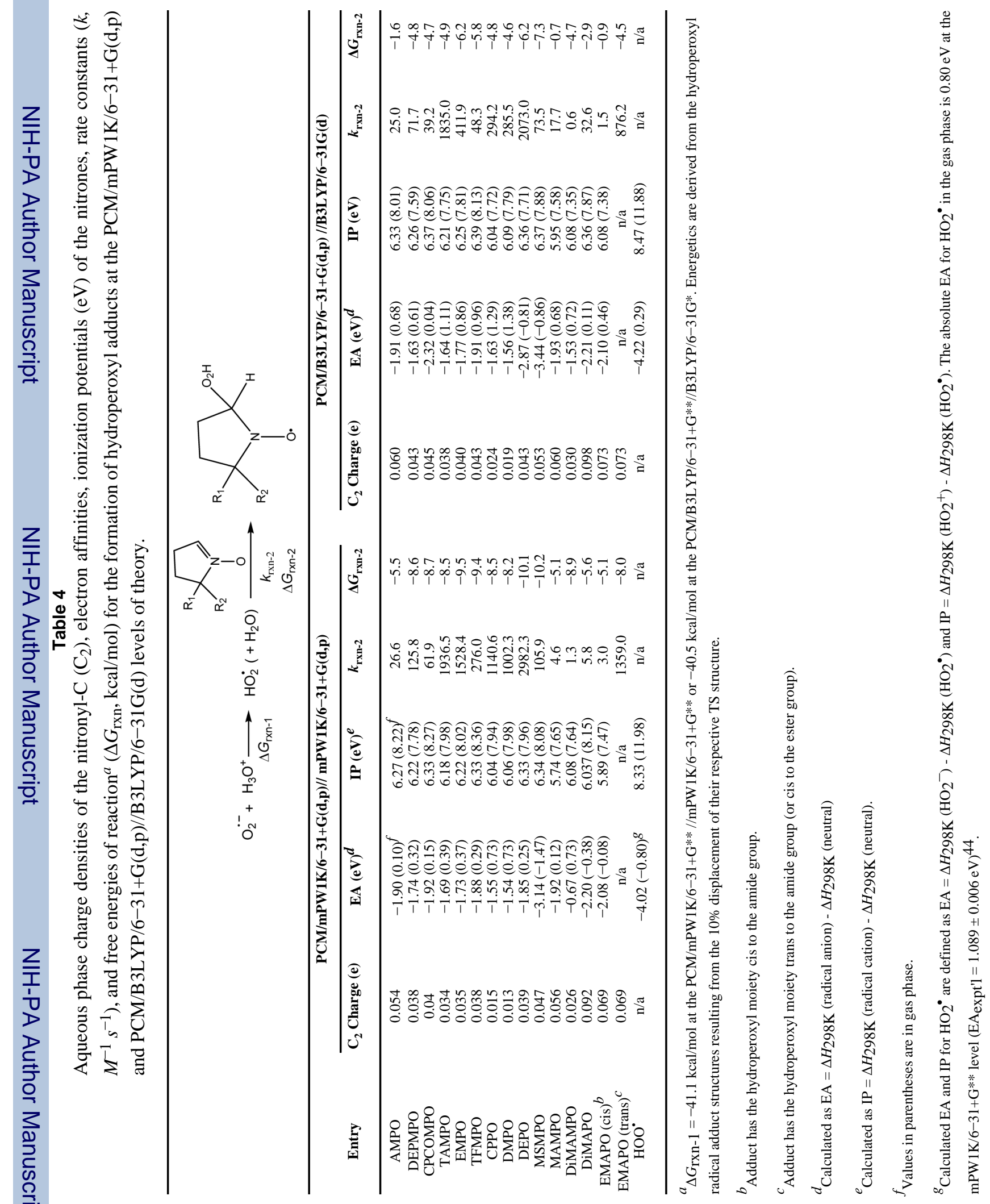

